Ekspansi: Jurnal Ekonomi, Keuangan, Perbankan dan Akuntansi

ISSN (Online): 2580-7668 ISSN (Print): 2085-5230

Vol. 13, No. 2 (November 2021), Hal. 178 - 191

\title{
FAKTOR FAKTOR YANG MEMPENGARUH MINAT RUMAH SAKIT ISLAM DI JAWA TIMUR MEMILIH SOFTWARE APLIKASI "SI AISAH” PLJSIAS UMSURABAYA
}

\author{
Anna Marina ${ }^{1}$, Warsidi ${ }^{2}$, Sentot Imam Wahjono ${ }^{3}$, Sabri Balafif ${ }^{4}$, Tri Kurniawati ${ }^{5}$ \\ 1,2,3,4,5 Universitas Muhammadiyah Surabaya \\ Email Korespondensi: warsidi@pps.um-surabaya.ac.id
}

Abstract: This study aims to determine the interest of Islamic hospitals in East Java in choosing the sharia sofware application "SI AISAH" from the Sharia Accounting Information System Service Centre (PLJSIAS) University of Muhammadiyah Surabaya. This research is a quantitative research using Statistical Package for the Social Sciences Software IBM SPSS version 23. The variables used ini this study are: Sharia, User Safety, Prices, and User Friendly. The population in this study were the leader and employees of Islamic hospital in East Java who were involved with the use of this sofware. Sampling using random sampling tehnique, with a total sample of 105 respondents. The results of the analysis show that the factors that influence the decision of Islamic hospitals in East Java to choose the "SI AISAH" software applicatin from PLJSIAS UMSurabaya are: Sharia (X1), User Safety (X2), Prices (X3), and User Friendly (X4). These four factors influence the decision of Islamic hospitals in East Java in choosing the "SI AISAH" software application only $69,9 \%$, while the remaining 30,1\% in influenced by other factor, and the most significants factor is the sharia factor (X1).

Keywords: sharia application software; PLJSIAS, aisah's application; UMSurabaya

Abstrak: Penelitian ini bertujuan untuk mengetahui minat rumah sakit rumah sakit islam di Jawa Timur dalam memilih aplikasi sofware syariah "SI AISAH" dari Pusat Layanan Jasa Sistem Informasi Akuntansi Syari'ah (PLJSIAS) Universitas Muhammadiyah Surabaya. Penelitian ini adalah penelitian kuantitatif dengan menggunakan Statistical Package for the Social Sciences, Software IBM SPSS versi 23. Variable yang digunakan dalam penelitian ini adalah : Kesyar'ian, Keamanan Penggunaan, Harga, dan Kemudahan Penggunaan. Populasi dalam penelitian ini adalah pimpinan dan karyawan rumah sakit rumah sakit islam di Jawa Timur yang terlibat dengan penggunaan sofware ini. Pengambilan sample menggunakan teknik random sampling, dengan jumlah sample 105 responden. Hasil analisis menunjukkan bahwa faktor-faktor yang mempengaruhi keputusan rumah sakit rumah sakit islam di Jawa Timur memilih aplikasi sofware "SI AISAH" dari PLJSIAS UMSurabaya adalah : Kesyar'ian X1, Keamanan Penggunaan (X2), Harga (X3), Kemudahan Penggunaan (X4). Keempat faktor tersebut mempengaruhi keputusan rumah sakit rumah sakit Islam di Jawa Timur dalam memilih aplikasi sofware SI AISAH (Y) sebesar 69,9\%, sedangkan sisanya sebesar 30,1\% dipengaruhi oleh faktor lain. Adapun faktor yang paling signifikan adalah faktor sharia (X1)

Kata Kunci: sofware aplikasi syariah; PLJSIAS; aplikasi si aisah; UMSurabaya 


\section{PENDAHULUAN}

Dalam rangka untuk memenuhi kebutuhan masyarakat akan kesehatan, maka banyak berdiri rumah sakit-rumah sakit di Indonesia hingga jumlahnya hampir mencapai tiga ribuan, Listyani (2019), sehingga kebutuhan tentang layanan kesehatan sudah terpenuhi dengan baik bahkan sampai ke pelosok-pelosok desa di seluruh Indonesia. Masyhudi (2020), menyatakan bahwa dari sekitar 3000 rumah sakit di indonesia, 500 diantaranya adalah rumah sakit islam dan sebanyak 20 rumah sakit telah mendapatkan sertifikasi sebagai rumah sakit syariah. Perkembangan jumlah rumah sakit-rumah sakit di Jawa Timur menduduki peringkat pertama tingkat propinsi. Adapun peringkat 10 besar jumlah rumah sakit tingkat propinsi adalah sebagai berikut : Propinsi Jawa Timur : 381 RS, Propinsi Jawa Barat : 350 RS, Propinsi Jawa Tengah : 290 RS, Propinsi Sumatera Utara: 211 RS, DKI Jakarta : 203 RS, Propinsi Banten : 112 RS, Propinsi Sulawesi Selatan: 106 RS, Daerah Istimewa Yogyakarta : 82 RS, Propinsi Sumatera Selatan: 78 RS, Propinsi Sumatera Barat dan Propinsi Lampung masing-masing : 77 RS. Propinsi Jawa Timur merupakan peringkat pertama yang memiliki jumlah rumah sakit terbanyak di Indonesia. Hal ini tentunya sangat membanggakan bagi masyarakat Jawa Timur. Adapun dari jumlah 381 RS tersebut terdiri dari : Rumah sakit milik pemerintah, Rumah sakit milik swasta dalam negeri dan milik swasta asing. Rumah sakit milik pemerintah umumnya adalah rumah sakit rumah sakit umum atau rumah sakit konvensional artinya pengelolaannya tidak berdasarkan syariat agama tertentu. Sedangkan rumah sakit milik swasta terbagi menjadi dua, yaitu swasta asing dan swasta dalam negeri. Untuk rumah sakit swasta asing umumnya dikelola secara konvensional, sedangkan swasta dalam negeri terbagi menjadi : 1). Dikelola secara konvensional (tidak berdasarkan pada syariat agama tertentu), 2). Dikelola berdasarkan syariat agama tertentu : Rumah sakit katholik, rumah sakit kristen, rumah sakit hindu dan rumah sakit Islam. Dalam hal ini penulis akan fokus pada rumah sakit yang berbasis pada syariat agama Islam, mengingat : 1). Perkembangan rumah sakit-rumah sakit yang berbasis Islam sungguh sangat signifikan, 2). Karena mayoritas $(86,88 \%)$ penduduk Jawa Timur adalah beragama islam (https://databoks.katadata.co.id/datapublish/2021/09/30/sebanyak-8688-pendudukindonesia-beragama-islam diakses tgl 19 oktober 2021)

Adalah merupakan suatu keniscayaan bahwa adanya rumah sakit Islam yang menjalankan operasionalnya berdasarkan syariat Islam di Jawa Timur adalah harapan dan kebutuhan masyarakat Jawa Timur. Dewasa ini yang menjadi pertanyaan adalah apakah semua rumah sakit-rumah sakit Islam di Jawa Timur sudah menerapkan operasionalnya berdasarkan prinsip syariah, khususnya fokus tulisan ini adalah, apakah sudah menggunakan system informasi akuntansi (SIA) syariah. Realitas menunjukkan bahwa sebagian besar rumah sakit Islam di Indonesia, dan khususnya di Jawa Timur masih belum menerapkan system operasionalnya berdasarkan prinsip syariah. Hal ini merupakan tantangan tersendiri bagi para praktisi rumah sakit maupun praktisi ilmu ekonomi syariah, bagaimana agar semua rumah sakit islam bisa menjalankan system operasionalnya berdasarkan system syariah. Oleh karena itu, agar tidak terjadi semacam pembohongan publik, bukan namanya saja rumah sakit islam tetapi operasionalnya 
menggunakan system konvensional, maka tujuan akhirnya adalah semua rumah sakit islam benar-benar menerapkan system operasionalnya berdasarkan system syariah, mengingat pada umumnya masyarakat awam khususnya para user /customer yang menggunakan jasa pelayanan rumah sakit yang berlabel islam, salah satu dasarnya adalah karena keyakinan akan kesyar'ian operasionalnya rumah sakit itu.

Dalam tulisan ini fokus penulis adalah penerapan SIA (System Informasi Akuntansi) syariah di rumah sakit rumah sakit Islam Jawa Timur. Kebutuhan laporan keuangan rumah sakit yang sesuai dengan prinsip-prinsip syariah sangat mendesak, khususnya bagi rumah sakit yang sudah terakreditasi sebagai rumah sakit syariah, demikian juga bagi rumah sakit yang dimiliki oleh ormas Islam yang bersiap menuju rumah sakit syariah. Terdapat dua masalah mendasar yang menyebabkan hal itu, yaitu ketiadaan software sistem informasi akuntansi syariah dan ketersediaan sumber daya manusia baik dari sisi jumlah maupun kualitasnya. Untuk mengatasi hal itu, fokus dalam penelitian adalah penyediaan System Informasi Akuntasi Syariah beserta sofwarenya yang bisa digunakan sebagai media membukukan transaksi berdasarkan System Akuntansi Syariah.

\section{TINJAUAN PUSTAKA}

\section{SOFTWARE APLIKASI "SI AISAH"}

Sofware aplikasi "SI AISAH" yaitu Sofware aplikasi syariah berbasis webb yang menggunakan system "codeigniter const CI_VERSION = '3.1.9' yang diciptakan oleh PLJSIAS: Pusat Layanan Jasa Sistem Informasi Akuntansi Syariah Universitas Muhammadiyah Surabaya. CodeIgniter (2017) diklaim memiliki performa yang cukup cepat dibandingkan framework-framework seperti Cake, Symfony, Yii, dan Laravel. Adapun kelebihan yang dimiliki oleh cdeIgniter antara lain: berukuran sangat kecil (file download_nya hanya sekitar 2MB termasuk dokumentasi lengkap, dokumentasinya bagus, hal ini sangat diperlukan khususnya dalam hal pembukuan, kompatibilitasnya sangat bagus karena mampu berjalan dengan baik pada hampir semua platfom hosting dan juga mendukung data base -data base paling umum, termasuk MySQL. Sofware ini sudah terbukti layak untuk digunakan sebagai aplikasi berbasis syariah yang memang diperlukan oleh rumah-sakit rumah-sakit Islam, karena sudah melalui proses User Acceptance Test (UAT) atau Uji Penerimaan Pengguna, yaitu suatu proses pengujian oleh pengguna yang menghasilkan dokumen yang dijadikan bukti bahwa software yang telah dikembangkan layak diterima oleh pengguna, karena hasil pengujian (testing) dianggap memenuhi keperluan dari pengguna. UAT dari sofware "SI AISAH" telah dilakukan dengan menggunakan (dami) data riil rumah sakit Muhammadiyah di Jawa Timur dan hasilnya sangat baik dan bisa dipertanggung jawabkan. Keunggulan dari sofware ini adalah 1). Aplikasi ini terbukti kesyar'iannya karena penciptaanya melibatkan para ahli akuntansi syariah baik dari Ikatan Akuntan Indonesia yang membidangi Ekonomi Syariah maupun para praktisi rumah sakit islam. 2). Aplikasi ini terjamin keamanan penggunaanya dalam membukukan transaksi berbasis syariah. 3). Aplikasi ini harganya tergolong murah dan sangat terjangkau, dan 4). Aplikasi ini tergolong mudah digunakan karena berbasis web. 


\section{MINAT}

Kamus Umum Bahasa Indonesia, Badududan Zain (1996) menyatakan bahwa: "1) minat, adalah apa yang disukai dan disenangi. 2) kepedulian, kesiapan untuk memperhatikan”. Sedangkan Peter dan Olson (1999): menyakatan bahwa minat adalah "Perhatian berkonotasi dengan kesadaran. Minat merupakan landasan penting bagi seseorang untuk melakukan kegiatan dengan baik yaitu dorongan seseorang untuk berbuat dalam Purwanto (2011). Secara bahasa minat berarti kecenderungan hati yang tinggi terhadap sesuatu. Minat merupakan sifat yang relatif menetap pada diri seseorang. Minat besar sekali pengaruhnya terhadap kegiatan seseorang sebab dengan minat ia akan melakukan sesuatu yang diminatinya. Sebaliknya tanpa minat seseorang tidak mungkin melakukan sesuatu, Purwanto (2011). Sedangkan menurut Slameto (2010) menjelaskan bahwa minat adalah suatu rasa lebih suka dan rasa keterikatan pada suatu hal atau aktivitas, tanpa ada yang menyuruh. Minat pada dasarnya adalah penerimaan akan suatu hubungan antara diri sendiri dengan sesuatu di luar diri. Semakin kuat dan dekat hubungan tersebut, semakin besar minatnya, Djaali (2008).

\section{KESYAR'IAN}

Syari'ah atau syar'i secara etimologi adalah aturan atau ketetapan yang Alloh perintahkan kepada hamba-Nya. Kata syariat berasal dari kata syar'a al syai'u yang berarti menerangkan atau menjelaskan sesuatu. Syaikh Muhammad bin Shalih al'Utsaimin rahimahullaah, $(1420 \mathrm{H})$ menyatakan bahwa syar'i, yaitu ilmu yang diturunkan oleh Allah Ta'ala kepada Rasul-Nya berupa keterangan dan petunjuk. Maka, ilmu yang di dalamnya terkandung pujian dan san-jungan adalah ilmu wahyu, yaitu ilmu yang diturunkan oleh Alloh SWT. Secara istilah syariah dapat diartikan sebagai suatu sistem atau aturan yang bisa jadi mengatur hubungan antara manusia dengan Alloh, atau hubungan manusia dengan manusia. Imam Abu Muhammad Ali bin Hazm dalam kitab Al-Hikam fi Ushulil Ahkam membeberkan bahwa jika terdapat teks yang tidak multitafsir dari Alquran, hadis, taqrir Nabi Muhammad SAW, serta para sahabat, tabiin, tabi' tabiin, ataupun konsesus ulama. Sedangkan secara luas arti dari assyari'ah adalah bahwa seluruh ajaran Islam yang berupa norma-norma ilahiyah, baik yang mengatur tingkah laku batin atau kepercayaan maupun tingkah laku konkrit. Syari'ah dalam arti sempit berkaitan dengan fikih yang salah satu aspeknya adalah ibadah, sehingga dapat ditarik kesimpulan, bahwa syar'i adalah memenuhi syarat dan kriteria yang bersumber dari Al-Qur'an dan Hadits. Allah SWT telah mengabadikan keberadaan syariah bagi umat Muslim dalam Alquran, surah al-Maidah ayat 48 yang artinya: "Untuk tiap-tiap umat di antara kamu, kami berikan aturan dan jalan yang terang,".

\section{KEAMANAN PENGGUNAAN}

Potter dan Perry (2006) mengemukakan pada dasarnya setiap individu memiliki kebutuhan dasar yang harus dan ingin dipenuhi. Pemenuhan kebutuhan ini dimulai dari tingkatan yang paling bawah, dan ketika kebutuhan yang paling dasar terpenuhi, maka akan muncul kebutuhan yang lebih tinggi dan menuntut untuk dipenuhi pula 
dan seterusnya. (Walgito, 2010), mengatakan bahwa salah satu kebutuhan itu adalah kebutuhan akan rasa aman atau keamanan. Dalam Kamus Besar Bahasa Indonesia aman berarti terbebas dari segala ancaman gangguan, bahaya dan terhindar serta terlindungi dari perasaan takut. Sedangkan Sutanto dan Fitriana (2017) mengatakan bahwa kebutuhan akan rasa aman adalah kebutuhan untuk melindungi diri dari berbagai bahaya yang mengancam. Bagian dari kebutuhan akan keamanan diantaranya termasuk keteraturan, hukum, ketentraman, perlindungan, keamanan fisik, bebas dari kekuatan yang mengancam seperti perang, kerusuhan dan bahaya.

\section{HARGA}

Kotler dan Amstrong (2008) mengatakan bahwa harga adalah sejumlah uang yang ditagihkan atas suatu produk atas jasa atau jumlah dari nilai yang ditukarkan para pelanggan untuk memperoleh manfaat dari memiliki atau menggunakan suatu produk atau jasa. Sedangkan menurut Tjiptono dan Chandra (2012) harga merupakan satu satunya bauran pemasaran yang mendatangkan pendapatan. Sehubungan dengan produk ini, Kotler dan Amstrong (2018) mengatakan bahwa produk adalah segala sesuatu yang dapat ditawarkan kepasar untuk mendapatkan perhatian, dibeli, digunakan atau dikonsumsi yang dapat memuaskan keinginan atau kebutuhan. Dengan demikian harga sangat terkait dengan kualitas produk. Pada umumnya konsumen akan memilih produk dengan kualitas yang baik dan harganya terjangkau.

\section{KEMUDAHAN PENGGUNAAN}

Mita Nur, Aulia (2012), mengatakan bahwa kemudahan penggunaan (user friendly) sebagai suatu tingkatan dimana seseorang percaya bahwa komputer (perangkat keras dan perangkat lunak : software) dapat dengan mudah dipahami, artinya bebas dari kesulitan dalam menggunakannya, sehingga akan mengurangi usaha (baik waktu dan tenaga) seseorang didalam mempelajarinya. Jogiyanto (2007), menyatakan Kemudahan Penggunaan juga didefinisikan sebagai sejauh mana seseorang percaya bahwa menggunakan suatu teknologi akan bebas dari usaha. Dengan menerapkannya ke dalam konteks penelitian, "kemudahan penggunaan" adalah bahwa operasional penggunaan software aplikasi "SI AISAH" akan mudah dilaksanakan tanpa kesulitan, artinya orang awampun akan mudah mengerti, memahami dan mengoperasikan software ini. Menurut TAM, "kemudahan penggunaan" memiliki dua efek, yaitu efek langsung maupun tidak langsung pada minat konsumen untuk mimilih suatu produk, dan dalam penelitian ini adalah software aplikasi "SI AISAH".

\section{METODE PENELITIAN}

Penelitian ini menggunakan metode kuantitatif, dengan menekankan analisis pada data-data numerical (angka) yang diolah menggunakan metode statistika ${ }^{2}$. Populasi dalam penelitian ini adalah pimpinan dan karyawan rumah sakit islam di Jawa Timur, dengan jumlah sampel sebesar 105 responden. Sumber data dalam penelitian ini adalah data primer yang diperoleh dengan cara menyebarkan kuesioner ke responden. Kuesioner disebarkan kepada responden dilakukan melalui media sosial 
yang terintegrasi dengan google form. Metode statistik yang digunakan dalam penelitian ini adalah analisis regresi linear berganda dengan variable yang digunakan adalah Kesyar'ian (X1), Keamanan (X2), Harga (X3), Kemudahan Penggunaan (X4) dan Minat memilih software aplikasi "SI AISAH" (Y).

\section{HASIL DAN PEMBAHASAN}

\section{Gambaran Umum Responden}

Gambaran umum responden digunakan untuk mengetahui keragaman dari responden (pimpinan dan karyawan) rumah sakit Islam di Jawa Timur berdasarkan jenis kelamin responden, usia responden, pendidikan terakhir responden serta status sebagai pimpinan atau karyawan rumah sakit islam di Jawa Timur.

\section{a. Jenis Kelamin}

Responden dalam penelitian ini didominasi oleh responden wanita yaitu sebanyak 65 responden, sedangkan responden pria sebanyak 40 responden sebagaimana terlihat pada tabel 1 berikut :

Tabel 1. Jenis Kelamin Responden

\begin{tabular}{|c|c|c|}
\hline Jenis Kelamin & Jumlah & Persentase \\
\hline Wanita & 65 & $61,90 \%$ \\
\hline Pria & 40 & $38,10 \%$ \\
\hline Total & 105 & $100,00 \%$ \\
\hline
\end{tabular}

Sumber: Data diolah (2021)

\section{b. Usia}

Responden pada penelitian ini berusia antara dalam rentang 20 sampai dengan 55 tahun. Responden yang berusia antara 20-30 tahun tercatat sebesar 33,33\% dari total keseluruhan responden. Sedangkan responden yang partisipasinya paling besar adalah yang berusia antara 31-40 tahun yaitu sebesar 47,62\%. Hal ini mengingat usia ini adalah usia emas pagi karyawan dan pimpinan rumah sakit islam, mereka adalah pihak yang berkepentingan dengan teknologi khususnya aplikasi yang berbasis web, di usia ini mereka akan sangat mudah menyesuaikan diri dengan alih teknologi dan lain lain. Sementara responden yang berusia $41-55$ tahun sebanyak $18,10 \%$ dari total responden. Usia ini usia yang matang dan banyak diantara mereka tidak terlalu paham teknologi. Sedangkan responden yang berusia diatas 55 tahun hanya 1 responden atau 0,95\% dari total responden. Hasil survey dapat dilihat pada tabel 2

Tabel 2. Usia Responden

\begin{tabular}{|c|c|r|}
\hline Usia & Jumlah & Persentase \\
\hline $20-30$ tahun & 35 & $33,33 \%$ \\
\hline $31-40$ tahun & 50 & $47,62 \%$ \\
\hline $41-55$ tahun & 19 & $18,10 \%$ \\
\hline$>55$ tahun & 1 & $0,95 \%$ \\
\hline Total & 105 & $100,00 \%$ \\
\hline
\end{tabular}

Sumber: Data diolah (2021) 


\section{c. Pendidikan Terakhir}

Target market dari software aplikasi "SI AISAH" adalah stake holder (pimpinan dan karyawan) rumah sakit rumah sakit Islam di Jawa Timur. Berdasarkan Data yang diteliti, sebaran pendidikan responden adalah sebagaimana dalam tabel 3 berikut:

Tabel 3. Pendidikan Terakhir Responden

\begin{tabular}{|c|c|c|}
\hline Pendidikan Terakhir & Jumlah & Responden \\
\hline SMA & 7 & $6,67 \%$ \\
\hline D3 & 20 & $19,05 \%$ \\
\hline S1 & 75 & $71,43 \%$ \\
\hline S2 & 3 & $2,86 \%$ \\
\hline Total & 105 & $100 \%$ \\
\hline
\end{tabular}

Sumber: Data diolah (2021)

Dalam Tabel 3 menunjukkan bahwa sebanyak 71,43\% responden adalah lulusan S1, sebanyak 19,05\% lulusan D3, lulusan SMA sebanya 6,67\% dan lulusan S2 sebanyak $2,86 \%$

\section{d. Status Karyawan}

Rata rata responden akan pimpinan dan karyawan rumah sakit rumah sakit Islam di Jawa Timur yang pekerjaan sehari harinya bergelut dengan urusan penggunaan software di rumah sakit, mulai dari pimpinan operasional rumah sakit islam (kepala devisi dan kepala bagian), kepala bagian kepala bagian: akunting, bagian teknologi dan informasi, Staff : kasir dan customer service, dan data tersebut dapat dilihat pada tabel 4 berikut :

Tabel 4. Status Pensiunan

\begin{tabular}{|c|c|c|}
\hline Status Pensiunan & Jumlah & \multicolumn{1}{c|}{ Persentase } \\
\hline $\begin{array}{c}\text { Karyawan Pimpinan (kepala devisi dan kepala } \\
\text { urusan) }\end{array}$ & 21 & $20,00 \%$ \\
\hline Kepala bagian & 35 & $33,33 \%$ \\
\hline Karyawan staff & 49 & $46,67 \%$ \\
\hline Total & 105 & $100,00 \%$ \\
\hline
\end{tabular}

Sumber: Data diolah (2021)

Berdasarkan data dalam penelitian ini sebagaimana ditunjukkan pada Tabel 4 menunjukkan bahwa sebanyak $46,67 \%$ adalah karyawan staff yang umumnya menangani operasional kegiatan rumah sakit, sehingga mereka memang benar-benar mengetahui software yang dibutuhkan oleh rumah sakit rumah sakit islam di Jawa Timur. Sementara kepala bagian sebanyak 33,33\%, karena mereka adalah menguasai teknologi juga mampu berkomunikasi kengan pihak atasan. Sedangkan 20\% adalah karyawan pimpinan yang memang bisa memutuskan untuk memilih software apa yang akan digunakan di rumah sakit yang mereka pimpin, sehingga operasional rumah sakit bisa berjalan lancar tanpa hambatan yang berarti 


\section{Uji Validitas dan Reliabilitas}

Uji validitas dan reliabilitas digunakan untuk mengetahui apakah alat ukur yang digunakan sudah dapat memenuhi apa yang ingin diukur dan menunjukkan konsistensi suatu alat pengukur. Suatu instrumen dikatakan valid jika instrumen tersebut dapat mengukur apa yang seharusnya diukur. Dan dikatakan reliabel jika ada kesesuaian antara alat ukur dengan yang diukur, sehingga alat ukur itu dapat dipercaya atau dapat diandalkan (Sugiyono,2018). Pengujian validitas dalam penelitian ini menggunakan validitas item dengan bantuan software SPSS. Dengan menggunakan taraf signifikansi atau tingkat kesalahan $(\alpha) 5$ persen, didapatkan hasil sebagai berikut:

Tabel 5. Hasil Uji Validitas

\begin{tabular}{|l|l|l|l|l|}
\hline Variabel & Item & r hitung & r tabel & Ket \\
\hline Kesyar'ian (X1) & X1.1 & 0,569 & 0,3610 & Valid \\
\cline { 2 - 5 } & X1.2 & 0,657 & 0,3610 & Valid \\
\cline { 2 - 5 } & X1.3 & 0,771 & 0,3610 & Valid \\
\cline { 2 - 5 } & X1.4 & 0,642 & 0,3610 & Valid \\
\cline { 2 - 5 } & X1.5 & 0,584 & 0,3610 & Valid \\
\hline \multirow{4}{*}{$\begin{array}{l}\text { Keamanan } \\
\text { Penggunaan (X2) }\end{array}$} & X2.1 & 0,752 & 0,3610 & Valid \\
\cline { 2 - 5 } & X2.2 & 0,512 & 0,3610 & Valid \\
\cline { 2 - 5 } & X2.3 & 0,663 & 0,3610 & Valid \\
\cline { 2 - 5 } & X2.4 & 0,857 & 0,3610 & Valid \\
\cline { 2 - 5 } & X2.5 & 0,478 & 0,3610 & Valid \\
\hline Harga (X3) & X3.1 & 0,864 & 0,3610 & Valid \\
\cline { 2 - 5 } & X3.2 & 0,565 & 0,3610 & Valid \\
\cline { 2 - 5 } & X3.3 & 0,677 & 0,3610 & Valid \\
\cline { 2 - 5 } & X3.4 & 0,613 & 0,3610 & Valid \\
\cline { 2 - 5 } X3.5 & 0,859 & 0,3610 & Valid \\
\hline Kemudahan & X4.1 & 0,747 & 0,3610 & Valid \\
\cline { 2 - 5 } & X4.2 & 0,697 & 0,3610 & Valid \\
\cline { 2 - 5 } & X4.3 & 0,735 & 0,3610 & Valid \\
\cline { 2 - 5 } & X4.4 & 0,788 & 0,3610 & Valid \\
\cline { 2 - 5 } & X4.5 & 0,589 & 0,3610 & Valid \\
\hline
\end{tabular}

Hasil uji validitas didapatkan pada Tabel 5 menunjukkan bahwa keseluruhan item pertanyaan mempunyai nilai $r$ hitung $\geq \mathrm{r}$ tabel $(0,3610)$ sehingga dapat disimpulkan bahwa semua item pertanyaan dari kelima variabel X1, X2, X3, X4 dan Y adalah valid.

Tabel 6. Hasil Uji Reliabilitas

\begin{tabular}{|l|l|l|l|}
\hline Variabel & $\begin{array}{l}\text { Koefisien } \\
\text { Alpha }\end{array}$ & $\begin{array}{l}\text { Nilai } \\
\text { Kritis }\end{array}$ & Keterangan \\
\hline Kesyar'ian & 0,751 & 0,600 & Reliabel \\
\hline $\begin{array}{l}\text { Keamanan } \\
\text { Penggunaan }\end{array}$ & 0,657 & 0,600 & Reliabel \\
\hline Harga & 0,881 & 0,600 & Reliabel \\
\hline $\begin{array}{l}\text { Kemudahan } \\
\text { Penggunaan }\end{array}$ & 0,732 & 0,600 & Reliabel \\
\hline
\end{tabular}


Uji reliabilitas dengan metode Alpha (Cronbach's) pada semua item pertanyaan yang sudah valid. Pada pengujian reliabilitas, semua item pertanyaan dikatakan reliabel jika nilai koefisien alpha lebih besar dari nilai kritis yaitu 0,600. Dari Tabel 6 hasil uji reliabilitas terlihat bahwa semua nilai koefisien alpha pada semua variabel lebih besar dari 0,600 sehingga dapat disimpulkan bahwa semua item pertanyaan sudah reliabel.

\section{Uji Asumsi Klasik Regresi Linear Berganda}

Uji asumsi klasik regresi linear berganda meliputi uji normalitas, uji homoskedastisitas, dan uji multikolinearitas.

\section{a. Normalitas}

Untuk uji normalitas secara visual dapat menggunakan histogram dan normal probability plot. Dengan bantuan software SPSS didapatkan histogram dan normal probability plot dan histigram sebagaimana ditunjukkan pada gambar 1 dan gambar 2 berikut.

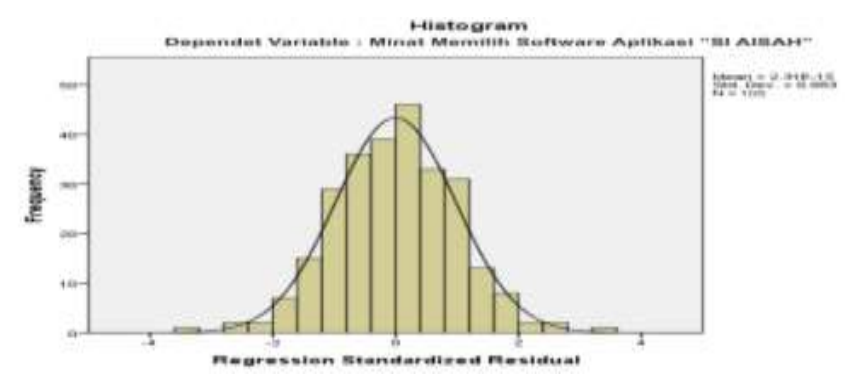

Gambar 1 Histogram

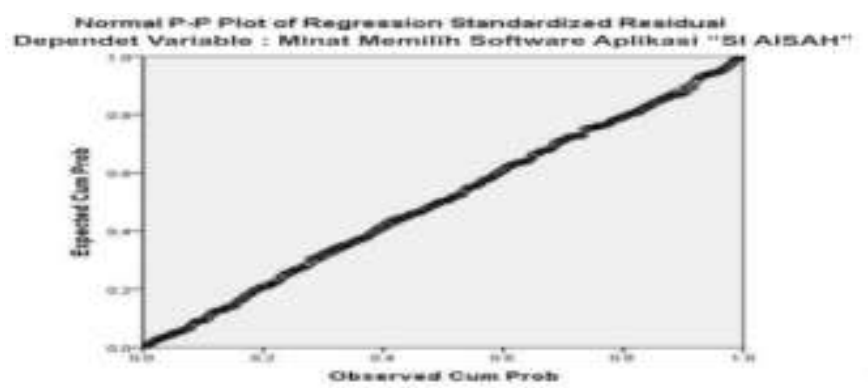

Gambar 2 Normal Probability Plot

Berdasarkan gambar histogram dan gambar normal probability plot diatas menunjukkan bahwa bentuk histogram menyerupai lonceng dan normal probability plot sebaran errornya masih ada di sekitar garis lurus, sehingga dapat dikatakan bahwa model regresi pada penelitian ini memenuhi asumsi normalitas.

\section{b. Homoskedastisitas}

Singgih Santoso (2016), mengatakan bahwa untuk mengetahui apakah model regresi memenuhi asumsi homoskedastisitas yaitu dengan membuat scatterplot antara prediksi variabel independen (ZPRED) dengan residualnya (SRESID), dan Hasil dari scatterplotnya adalah sebagai berikut: 


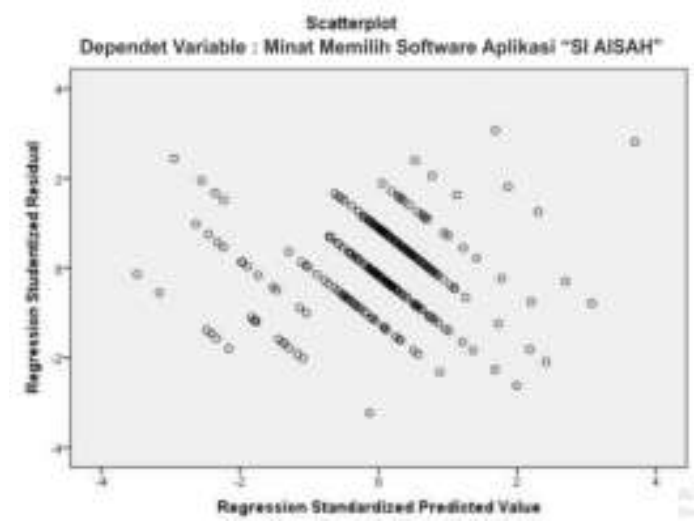

Gambar 3 Scatterplot

Berdasarkan scatterplot pada gambar 3 menunjukkan bahwa tidak ada pola yang jelas seperti titik-titik menyebar di atas dan di bawah angka nol pada sumbu Y, sehingga dapat disimpulkan bahwa tidak ada gejala heteroskedastisitas. Dengan kata lain model regresi sudah memenuhi asumsi homokesdastisitas.

\section{c. Multikolinieritas}

Singgih Santoso (2016), mengatakan untuk melihat apakah model regresi bebas dari multikolinearitas yaitu dengan melihat nilai tolerance dan nilai VIF. Model regresi dikatakan tidak terdapat masalah multikolinearitas jika nilai VIF berada dibawah 10,00 dan nilai Tolerance lebih dari 0,100 Hasil dari pengujian multikolinearitas pada model regresi ini sebagaimana ditunjukkan pada tabel 7 .

\section{Tabel 7 Hasil Uji Multikolinearitas}

\begin{tabular}{|l|c|c|}
\hline \multirow{2}{*}{ Variabel } & \multicolumn{2}{|c|}{ Collinearity Statistics } \\
\cline { 2 - 3 } & Tolerance & VIF \\
\hline Kesyar'ian (X1) & 0,765 & 1,308 \\
\hline $\begin{array}{l}\text { Keamanan Penggunaan } \\
\text { (X2) }\end{array}$ & 0,949 & 1,053 \\
\hline Harga (X3) & 0,484 & 2,065 \\
\hline $\begin{array}{l}\text { Kemudahan } \\
\text { Penggunaan (X4) }\end{array}$ & 0,432 & 2,315 \\
\hline
\end{tabular}

Berdasarkan hasil uji multikolinearitas pada tabel 7 terlihat bahwa nilai tolerance untuk semua variabel lebih besar dari 0,1 dan nilai VIF untuk semua variabel kurang dari 10. Sehingga dapat disimpulkan bahwa model regresi bebas dari multikolinearitas.

Dari uji asumsi klasik yang telah dilakukan yang meliputi uji normalitas, uji homoskedastisitas dan uji normalitas dapat disimpulkan bahwa model regresi pada penelitian ini telah memenuhi asumsi klasik regresi linear berganda sehingga bisa dilakukan untuk analisis selanjutnya. 


\section{Uji parsial terhadap faktor yang mempengaruhi minat stake holder rumah sakit islam memilih software aplikasi "SI AISAH"}

Untuk mengetahui faktor apa saja yang mempengaruhi ninat stake holder rumah sakit islam memilih software aplikasi "SI AISAH" digunakan analisis regresi linear berganda. Analisis regresi linear berganda ini digunakan untuk memodelkan antara minat stake holder memilih software aplikasi "SI AISAH" (Y) dengan faktor-faktor yang mempengaruhi yaitu Kesyar'ian (X1), Keamanan Penggunaan (X2), Harga (X3) dan Kemudahan Penggunaan (X4).

Dengan menggunakan software SPSS didapatkan hasil sebagai berikut:

Tabel 8. Pengujian Parsial

\begin{tabular}{|l|c|c|}
\hline \multicolumn{1}{|c|}{ Variabel } & Koefisien Regresi & P_value (sig) \\
\hline (Constant) & 4,984 & 0,005 \\
\hline Kesyar'ian (X1) & 0,111 & 0,010 \\
\hline Keamanan Penggunaan (X2) & 0,168 & 0,001 \\
\hline Harga (X3) & $-0,258$ & 0,000 \\
\hline Kemudahan Penggunaan (X4) & 0,212 & 0,000 \\
\hline
\end{tabular}

Sumber: Data diolah (2021)

Untuk memutuskan apakah variabel independen mempengaruhi variabel dependen selain menggunakan rumus t hitung juga bisa menggunakan nilai p_value. Jika nilai p_value lebih kecil dari taraf signifikansi $(\alpha)$ maka HO ditolak yang artinya ada pengaruh antara variabel independen terhadap variabel dependen (Sugiyono, 2018), demikian sebaliknya jika nilai p_value lebih besar atau sama dengan taraf signifikansi $(\alpha)$ maka HO diterima yang artinya tidak ada pengaruh antara variabel independen terhadap variabel dependen. Dalam penelitian ini digunakan taraf signifikansi $(\alpha)$ sebesar 5 persen. Berdasarkan Tabel 8 terlihat bahwa variabel yang berpengaruh secara parsial terhadap minat stake holder rumah sakit islam memilih software aplikasi "SI AISAH" adalah Kesyar'ian (X1), Keamanan (X2), Kemudahan (X3) dan Harga Murah (X4). Hal ini bisa dilihat dari nilai p_value lebih kecil dari taraf signifikansi $(\alpha)$.

\section{Uji simultan terhadap faktor yang mempengaruhi minat stake holder memilih software aplikasi "SI AISAH"}

Selanjutnya apabila dilakukan pengujian secara simultan atau bersama-sama dengan hipotesis sebagai berikut:

Ho : secara bersama-sama faktor kesyar'ian, keamanan, kemudahan dan harga murah, tidak berpengaruh terhadap minat stake holder dalam memilih software aplikasi "SI AISAH"

H1 : secara bersama-sama faktor kesyar'ian, keamanan, kemudahan dan harga murah, berpengaruh terhadap minat stake holder memilih software aplikasi "SI AISAH". Dari output SPSS didapatkan hasil sebagai berikut : 
Tabel 9. Hasil Uji Simultan

\begin{tabular}{|l|l|l|c|c|c|}
\hline \multicolumn{1}{|c|}{ Model } & \multicolumn{1}{c|}{ SS } & \multicolumn{1}{c|}{ df } & \multicolumn{1}{c|}{ MS } & F & Sig \\
\hline Regression & 338,37 & 9 & 37,60 & 37,70 & 0,00 \\
\hline Residual & 256,33 & 257 & 0,997 & & \\
\hline Total & 594,70 & 266 & & & \\
\hline \multicolumn{7}{|c|}{ Sumber: Data diolah (2021) }
\end{tabular}

Dari tabel 10 didapatkan nilai p_value (sig) sebesar 0,000 dimana nilai tersebut lebih kecil dari nilai taraf signifikansi $(\alpha)$ sebesar 5 persen, sehingga Ho ditolak dan dapat disimpulkan bahwa secara bersama-sama faktor kesyar'ian, keamanan, kemudahan dan harga murah berpengaruh terhadap minat stake holder rumah sakit islam memilih software aplikasi "SI AISAH".

Selanjutnya keempat faktor tersebut akan berpengaruh terhadap minat stake holder rumah sakit islam memilih software aplikasi "SI AISAH" hanya sebesar 69,9\% , sisanya sebesar 30,1\% dipengaruhi oleh faktor yang lain. Hal ini dapat dilihat pada nilai koefisien determinasi (R-square) pada output SPSS. Sebanyak 30,1\% itu kemungkinan adalah tingkatan trust (percaya) pada saat akan memilih software aplikasi "SI AISAH". Adapun model regresi pada penelitian ini adalah sebagai berikut:

$$
Y=4,984+0,258 X 1+0,168 X 2-0,111 X 3+0,151 X 4
$$

Artinya tanpa pengaruh dari faktor manapun, pimpinan dan karyawan rumah sakit islam Jawa Timur telah menunjukkan minat memilih software aplikasi "SI AISAH" pada tingkatan 4,984. Apabila kesyar'ian meningkat sebesar 1\% maka minat memilih akan meningkat sebesar 0,258\%. Apabila keamanan penggunaan meningkat sebesar $1 \%$ maka minat memilih software aplikasi "SI AISAH"akan naik sebesar 0,168\%. Selanjutnya jika harga aik 1\% maka minat memilih software aplikasi "SI AISAH" akan turun sebesar $0,111 \%$ dan sebaliknya jika harga turun $1 \%$ maka minat memilih software aplikasi "SI AISAH" akan naik sebesar 0,111\%. Jika faktor kemudahan penggunaan naik sebesar 1\% maka minat memilih software aplikasi "SI AISAH" akan naik sebesar $0,151 \%$ dan jika kemudahan penggunaan naik sebesar $1 \%$ maka minat memilih software aplikasi "SI AISAH" juga akan naik sebesar 0,151\%.

\section{Faktor yang paling signifikan mempengaruhi minat rumah sakit Islam memilih software aplikasi "SI AISAH"}

Faktor yang paling signifikan mempengaruhi minat rumah sakit Islam di Jawa Timur memilih software aplikasi "SI AISAH" dari PLJSIAS UMSurabaya adalah faktor kesyar'ian. Hal ini bisa dilihat dari nilai koefisien regresi yang paling besar dibandingkan dengan faktor yang lain. Selain itu bisa dilihat dari hasil kuesioner yang menunjukkan bahwa tidak ada satupun responden yang tidak setuju dengan pertanyaan yang diberikan. Hal ini menujukkan bahwa para user yaitu pimpinan dan karyawan rumah sakit islam di Jawa Timur ini benar benar mengharapkan adanya aplikasi syariah sehingga memilih software aplikasi "SI AISAH" dari PLJSIAS UMSurabaya. 
190 Anna Marina, Warsidi, Sentot Imam Wahjono, Sabri Balafif dan Tri Kurniawati

\section{KESIMPULAN}

Kesimpulan dalam penelitian ini adalah sebagai berikut :

a. Faktor-faktor yang secara parsial berpengaruh terhadap minat rumah sakit islam di Jawa Timur memilih software aplikasi "SI AISAH" adalah Kesyar'ian (X1), Keamanan Penggunaan (X2), harga (X3), Kemudahan Penggunaan (X4)

b. Kesyar'ian (X1), Keamanan Penggunaan (X2), harga (X3), Kemudahan Penggunaan (X4) secara simultan berpengaruh terhadap minat rumah sakit islam di Jawa Timur memilih software aplikasi "SI AISAH". Keempat faktor tersebut mempengaruhi minat rumah sakit memilih software aplikasi "SI AISAH" 69,9\%, sisanya sebesar 30,1\% dipengaruhi oleh faktor yang lain.

c. Kesyar'ian merupakan variabel paling signifikan yang mempengaruhi minat rumah sakit islam di Jawa Timur memilih software aplikasi "SI AISAH" dari PLJSIAS UMSurabaya

\section{DAFTAR PUSTAKA}

A Potter, \& Perry, A. G. (2006). Buku Ajar Fundamental Keperawatan: Konsep, Proses, Dan Praktik, edisi 4, Volume.2. Jakarta: EGC.

Aulia, Mita Nur, (2012), "Pengaruh Manfaat Pengguna Dan Kemudahan Pengguna Teknologi Informasi Terhadap Model Penerimaan Teknologi (Technology Acceptance Model) Dan Dampaknya Terhadap Kinerja Auditor (Survei Pada Kantor Akuntan Publik Bandung)", Universitas Pasundan, Bandung

Badudu J.S dan Zain, Sutan Mohammad, (1996), Kamus Umum Bahasa Indonesia. Jakarta: Pustaka Sinar Harapan.

Bimo Walgito. (2010). Pengantar Psikologi Umum. Yogyakarta: Andi Offset Dahlan, U. A. (2016). E-Learning Dalam Persepsi Mahasiswa

CodeIgniter, (2017), Mengetahui Fungsi, Kelebihan dan Kekurangan Framework

CodeIgniter, https://idcloudhost.com/panduan/mengetahui-fungsi-kelebihandan-kekurangan-codeigniter/ diakses tgl 19 oktober 2021

Djaali, (2008), Psikologi Pendidikan, Jakarta: Bumi Aksara.

Jogiyanto, H.M., (2007), Sistem Informasi Akuntansi Berbasis Komputer : konsep dasar dan komponen, edisi dua,Yogyakarta:BPFE

Kotler, Philip; Armstrong, Garry, (2008), Prinsip-prinsip Pemasaran,Jilid 1, Erlangga, Jakarta.

Kotler, Philip; Amstrong, Gary (2018). Principles of Marketing. Edisi 15 Global Edition. Pearson.

L. T. E. Listyani,(2019), "Jumlah Rumah Sakit di Indonesia," Manajemen Rumah Sakit Masyhudi, (2020), "Mukisi Tambah Jumlah RS Syariah di Tahun 2019," Mukisi, Jakarta, p. 20

Peter, J. Paul \& Jerry C. Olson. (1999). Consumer Behavior, Perilakukonsumen dan Strategi Pemasaran.Jilid kedua, Edisi Keempat. Terjemahan Damos Sihombing dan Peter Remy Yossi Pasla. Jakarta: Erlangga.

Purwanto, (2011), Evaluasi Hasil Belajar. Yogyakarta: Pustaka Pelajar Singgih Santoso, (2016), Panduan Lengkap SPSS Versi 23 (Jakarta: Gramedia Direct 
Slameto, (2010), Belajar dan faktor faktor yang mempengaruhinya, Jakarta, Renika Cipta

Sugiyono, (2018), Metode Penelitian Kuantitatif Kualitatif Dan REDD, Bandung: Alfabeta

Sutanto, Andina Vita dan Fitriana, Yuni. (2018). Asuhan Pada Kehamilan. Yogyakarta: Pustaka Baru.

Syaikh Muhammad bin Shalih al-'Utsaimin rahimahullaah, (1420 H), Kitaabul 'ilmi, cet, Daar Tsurayya Iin Nasyr

Tjiptono, Fandy dan Chandra, Gregorius (2012), Service, Quality Satisfaction. Jogjakarta: Andi Offset. 